\title{
Participatory Management for Enhancing Students' Academic Performance in Public Secondary Schools in Rivers State
}

\author{
Ebunu, Akpofure Anna \\ Department of Educational Management Faculty of Education, \\ University of Port Harcourt Rivers State.
}

\begin{abstract}
This study investigated participatory management for enhancing students' performance in public secondary schools in Rivers State. The study adopted descriptive survey design. The population of the study was all the 276 principals and 8,452 teachers in public senior secondary schools as well as 4,455 students' parents. The sample of the study was 730 respondents, comprising 90 principals, 360 teachers and 280 parents who were selected through the combination of stratified sampling, simple random sampling and purposive sampling techniques. Instrument of data collection was 10 items questionnaire titled, "Teachers and Parents Participation in Secondary School Management Questionnaire (TPPSSMQ). The instrument was a validated four-point likert styled, Strongly Agree (SA), Agree (A), Disagree (D) and Strongly Disagree (SD). It has a reliability index of 0.82, using Cronbach Alpha Statistical test. The research questions were analysed using mean and standard deviation whereas the hypotheses were tested using z-test statistics at 0.05 alpha level. The findings of the study revealed that the involvement of teachers in school decision-making would give teachers broader opportunity to make inputs in policy issues that concern effective instructional delivery. The study further showed that the involvement of parents in school decision-making would give them ample platform to offer their advices on how to improve the quality of teaching and learning. Based on the findings, the study recommended that school managers should give teachers meaningful opportunities to make inputs, that such opportunities will empower them to take decisions on issues affecting their work performance and productivity for enhanced students' achievement. Furthermore, school authorities should accord parents' opportunities to offer their advices on how to enhance resource accountability to foster efficient school management and quality teaching and learning in the school.
\end{abstract}

Keywords: Participatory Management, Students' Performance, Secondary Schools.

\section{INTRODUCTION}

The increasing social changes driven by Information Communication Technology (ITC) and the resulting competitiveness in socio-political and economic environments have no doubt heightened 
Ebunu, A. A. (2020). Participatory Management for Enhancing Students' Academic Performance in Public Secondary Schools in Rivers State. Advances in Social Sciences Research Journal, 7(5) 145-156.

the challenges facing school managers. One of the major challenges has always centred on how to utilize scarce resources prudently to pursue and attain set educational goals. As the school system grapple with the ensuing social changes and associated implications in education sector, some educationist has drawn attention to the need for schools to improve the quality of education they offer to match the skill needs of the society.

It is true that before now, educationist and scholars use to give greater attention to teacher qualities and students' achievement in estimating quality school, however recent studies have shown that teacher's job performance and students' learning outcomes are just variables that depend on many other factors, among which include; individual school management structure and style, availability of educational resources and the quality of programmes provided to students under conducive environment as well as the quality of support an individual school receives from stakeholders (Lawal \& Yusuf, 2014). This understanding is supported by certain emerging philosophies that backs the infusion of collaborative and partnership ideologies in school management practices. Recent empirical studies had lent credence to the avowed benefits of involving stakeholders in organizational governance (Nwankwo, 2014:45), as the traditional totalitarian management approaches that rarely acknowledges workers' ability to make useful contribution to work structuring was no longer producing intended results (Duze, 2011:201). This is probably the reason why many organizations are now moving away from authoritarian management style to participatory approach that embraces decentralization of authority, job enrichment and empowerment that not only afford decision-making privileges to institutional members, but also reassures stakeholders' faith in the school's ability to improve academic performance of students. Such participatory decision-making process is considered necessary for not only building trust among vested interests in the organization, but also important for rousing and entrenching firmly, the culture of teamwork among organizational actors and diverse ranks of managers and subordinates. Stakeholders' involvement in school governance is driven by concerted commitment to democratization of decision-making process in a manner that gives students opportunities to air their collective views, empower communities and parents to make decisions on how to manage their schools, while at the same time providing necessary platform for encouraging external stakeholders, including employers of labour and non-governmental organizations, religious groups and labour organizations to make their respective inputs and feedbacks towards promoting effective school governance and academic performance of students. Such feedbacks and follow up suggestions help to shape curriculum modifications and reforms processes in education. Under this arrangement is conveyed the idea that every stakeholder matter, and their contributions valued by the school.

Participatory management is considered useful not just because it creates interactive forum for intersection of ideas and purposeful discussions that allow stakeholders, community leaders, parents, teachers and individuals student to make varying suggestions that may turn out to be innovative ideas that can improve school overall productivity. The logic behind these suppositions is because participative decision making has numerous benefits. Teachers for instance, are closer to students, and thus tend to understand them better, and perhaps have significant information that can inform good suggestions on better ways of doing their work effectively. However, if they are not involved in decision-making, some of them may be dissatisfied with the system because it does not offer platform for teachers to share perceived better ways of performing their work effectively. Obi (2003:278) argued that since teachers are the major implementers of educational policies and 
programmes, their active participation in policy formulation and programme networking to produce the desired result is important. Furthermore, Lawal and Yusuf (2011) added that participatory management in school helps teachers to present their work-related challenges to school council so that issues bothering on their welfare and work performance concerns are addressed. Despite the benefits of decentralized decision-making process, observations suggest that participatory management creates leadership challenges for teachers who by virtue of their involvement in decision-making are empowered with additional responsibilities tied with learning and growth opportunities. Duze (2011:203) remarked that teachers feel valued when principal delegate important duties to them or appoint them as ad hoc committee member.

In other hands, the huge inputs of parents in their children's education are not in dispute; a parent could be father, mother, or a guardian of the student. The important role of parents in education of their wards has been recognized long time ago. That is why the Nigerian government recognized their involvement in management of schools by instituting Parents Teachers Association (PTA); a body established to liaise with Post-Primary Education Management Board (PEMB) to promote quality education, moral uprightness among teachers and students, and conducive learning and healthy environment that favour academic excellence of students (Obi, 2003). Though PTA is recognized by the government, but they are not party to day-by-day school management routines. Ukaigwe and Igbozuruike (2019:98) stated that PTA synergise with school leadership in formulating policies that has far reaching implications on students' academic progression, moral and spiritual development of the school community and teacher disciplinary regulations grounded in teacher Code of Conduct. In addition, PTA continually develops modalities for raising fund needed to support the procurement of physical facilities and capacity-building programmes. Peretomode (1992:256) suggested that PTA in most*6African countries are functioning as advisory body, whose suggestions and inputs are in most case ignored by school management board and thus limited in effect. The scholar further made a case for decentralization of school decision-making process in such a way that gives authority to the resolutions of PTA. This proposition is supported by the idea that PTA is an important key channel via which parents can make thoughtful contribution to school management. This presupposes that PTA is supposed to be part of school decision-making body and should be recognized by relevant education statutes.

Meanwhile, the idea of involving stakeholders in school management is not entire new to educational management practices, and thus may not be the panacea the school system is yearning for, however, the benefits drivable from participatory management in areas of school effectiveness, social stability and improvement in students' achievements have remained undisputed in recent literature. This is not just because it helps to build trust among school community members for sustained motivation to accomplish shared objectives, but also because participatory school management boost the confidence of employees and gives them sway over their work life, ensures that parents and communities leaders work together to promote students' enrolment and sanitation in the school, strengthens discipline among staff and students, and also helps to garner supports for sustainable school performance effectiveness.

For instance, the School-based Management Committee (SBMC) system that comprised representatives of different groups and stakeholders was instituted mainly to strengthen schoolcommunity partnership in improving the quality of teaching and learning in Nigerian schools. Though the government take-over of schools in mid 1970s cut short the benefits of participatory 
Ebunu, A. A. (2020). Participatory Management for Enhancing Students' Academic Performance in Public Secondary Schools in Rivers State. Advances in Social Sciences Research Journal, 7(5) 145-156.

decision-making offered, as the enabling law effectively curtailed active participation of the communities and other stakeholders in school planning and management, and thus marked the beginning of gradual collapse of education system in Nigeria (Peretomde, 1992:133). This is because the society benefited so much from school-community collaboration then, with the result that the school system enjoyed the supports (projects, donations, and other benefits) it gained from the community. Ukaigwe and Igbozuruike (2019:90) made similarly observation when they remarked that schools that existed before the government takeover benefited from the inputs of Parents Teachers Association (PTA), whose contributions to decision-making helped to ensure that curriculum was adapted to socio-cultural and economic needs of the learners and peculiarities of the community, with the result that schools then were considered as having been administered effectively as their outputs then were relatively competent. This view is further supported by Mulwa, Kimosop and Kasivu (2015:62), who observed that active involvement of parents, community representatives in school decision-making helps to tailor the curriculum and instructional planning to the need of the learners and occupational needs of the community, thereby ensuring that graduates of community schools acquired functional skill that ought to help them transit into the wider society where they are expected to apply the skills they acquired to earn a living. Given the plausible character of participatory management in relation to effective school governance and academic productivity of students, the call for devolution of school authority and extension of its autonomy to accommodate vested interest and encourage purposeful participatory decision making process that maximizes individuals' productivity and students' educational outcomes is thus imperative.

Participatory management is school will require robust interpersonal skills on the part of major actors such as principals. This is necessary for fostering productive interactions among stakeholders who ought to connect and generates fresh ideas to deal with old and emerging educational challenges. Participatory management affords stakeholders (such as staff, students, parents, community representatives of the community and employers of labour, non-governmental bodies and other interest groups) the opportunity to participate in curriculum planning, financial and project management and others matters bordering on school effectiveness. Under participatory management, individual stakeholders can make input during council meetings and policy formulations, while resolutions reached in the process are implemented to produce the desired effect. Mullins (2008:48) asserted that power-play under participatory management rest with its democratic tenets and interactions that produced decisions during council meetings. Participatory management interrogates the propositions of traditional management practices as it not only encourages openness and inspires trust between the principal, teachers, parents and other stakeholders thereby creating environment conducive for searching for new ideas and solutions to challenges. Ebunu (2018:34) remarked that participatory management does not only help to decentralize school authority and enables teachers to uncover new challenges and embrace opportunities to foster their productivity, as it also helps to entrench school and teachers' autonomy - an important factor considered in literature as having bearing on academic achievement of students (Uwakwe et al, 2008:55).

The principal is at the centre and coordinator of school-based participatory management process; he or she is expected to foster collegial and productive relationship among students and teachers, collaborate with parents and community leaders and partner with external stakeholders who are expected to work as a team in interrogating identified challenges in education process in order to 
reach solutions and implement decisions to achieve set goals. Given the points highlighted above, this study is emboldened to explore the prospect of democratising and decentralizing decisionmaking process in public schools given that the current centralized management system seems to be defective given that it alienates stakeholders from making inputs on issues that concern their schools. It was against this background that this study examined how involvement of teachers and parents in school management to enhance students' achievement in secondary schools in Rivers State.

\section{STATEMENT OF THE PROBLEM}

Despite the good intensions of government to use schools as a tool for uniting the diverse ethnic groups for accelerated economic and social development, there are indications that the centralized management approach being used by the government to achieve its intensions is not producing the desired result in terms of producing skill oriented and morally sound graduates who can contribute meaningfully to societal development. The enormity of the deficiencies of centralised management style seems to be increasing along with the resulting deterioration in social values and labour market imperfections, of which pundits have blamed largely on non-participative character of current school management approach. No doubt these misgivings have placed fresh demands on school managers to rethink their managerial approach with a view to adopting participatory management style in which teachers and parents are involved in school planning and administration. Admittedly, the acute shortages of educational resources in public school and associated poor academic achievement of students in many communities is particularly worrisome and resonate the calls for involvement of internal and external stakeholders in planning and management of public school. The superiority of participatory management over centralized bureaucracy has been established in recent literature, and thus justifies the incorporation of its tenets in the management of public schools to contain the spiralling managerial difficulties. This study therefore investigated participative management with a view to finding out whether the involvement of teachers and parents in the management of public secondary schools in Rivers State can enhance students' academic performance.

\section{Aim and Objectives of this Study}

The aim of this study is to examine participatory management for enhanced students' academic performance in secondary schools in Rivers State. Specifically, the objectives of the study are to;

1. determine how teachers' participation in school management enhances academic performance of students in Rivers State.

2. find out how parents' participation in school management enhances academic performance of students in Rivers State.

\section{Research Questions}

The following research question guided the study

1. In what ways does teachers' participation in school management enhances students' academic performance in Rivers State?

2. In what ways does parents' participation in school management enhances students' academic performance in Rivers State?

\section{Hypotheses}

The following hypotheses guided the study. 
Ebunu, A. A. (2020). Participatory Management for Enhancing Students' Academic Performance in Public Secondary Schools in Rivers State. Advances in Social Sciences Research Journal, 7(5) 145-156.

1. There is no significant difference between the mean perceptions of principals and teachers on the ways teachers' participation in school management enhances students' academic performance in Rivers State.

2. There is no significant difference between the mean perception of principals and parents on the ways parents' participation in school management enhances students' academic performance in Rivers State.

\section{METHODOLOGY}

The study adopted descriptive survey design. The target population of the study was all the 276 principals and 8,452 teachers in senior secondary schools as well as 4,455 students' parents. The sample of the study was 730 respondents, comprising 90 principals, 360 teachers and 280 parents who were selected through the combination of stratified sampling, simple random sampling and purposive sampling techniques in 10 Local Government Areas in Rivers State. Instrument of data collection was a 10 items questionnaire titled, "Teachers and Parents Participation in Secondary School Management Questionnaire" (TPPSSMQ). The instrument was a validated four-point styled Likert instrument of Strongly Agree (SA), Agree (A), Disagree (D) and Strongly Disagree (SD). It has a reliability index of 0.82 , using Cronbach Alpha. The instrument consisted of two sections; Section A was used to elicit demographic data of the respondents, while section B included 10 items questionnaire items structured to obtain responses from the respondents. The data generated were analysed with the aid of SPSS, using mean, and standard deviation (SD) to answer research questions. Items that scored $x \geq 2.50$ were agreed whereas those below it disagreed. $z$-test statistics was used to test the hypotheses at 0.05 alpha level.

\section{Data Analysis and Results}

Research Question One: In what ways does teachers' participation in school management enhances students' academic performance in Rivers State?

Table 1: Mean scores and standard deviations (SD) of the ways teachers' participation in school management enhances students' academic performance in Rivers State

\begin{tabular}{|c|c|c|c|c|c|c|c|}
\hline \multirow{2}{*}{$S / n$} & \multirow{2}{*}{ Description of Items } & \multicolumn{3}{|c|}{ Principal } & \multicolumn{3}{|c|}{ Teachers } \\
\hline & & Mean & SD & Remarks & Mean & SD & Remarks \\
\hline 1. & $\begin{array}{l}\text { Involvement of teachers in school decision- } \\
\text { making will give teachers broader opportunities } \\
\text { to make inputs in matters that concern } \\
\text { instruction. }\end{array}$ & 2.78 & 0.81 & Agree & 3.02 & 0.79 & Agree \\
\hline 2. & $\begin{array}{l}\text { Increasing the decision-making powers of } \\
\text { teachers on their respective subject specialty } \\
\text { will enhance instructional effectiveness. }\end{array}$ & 2.81 & 0.67 & Agree & 3.31 & 0.89 & Agree \\
\hline 3 & $\begin{array}{l}\text { Teacher participation will create a platform for } \\
\text { robust discussion of school management issues } \\
\text { for greater efficiency. }\end{array}$ & 2.84 & 0.90 & Agree & 3.23 & 0.83 & Agree \\
\hline 4. & $\begin{array}{c}\text { Teachers participation in decision-making } \\
\text { builds relational trust which interplay with } \\
\text { other factors to enhance teacher-productivity } \\
\text { for enhanced students' achievement }\end{array}$ & 3.01 & 0.66 & Agree & 3.40 & 0.68 & Agree \\
\hline 5 & $\begin{array}{l}\text { Involvement of teachers in school decision- } \\
\text { making strengthens power balance to give } \\
\text { teachers control over their working lives }\end{array}$ & 2.77 & 0.87 & Agree & 3.00 & 0.79 & Agree \\
\hline & Grand Mean & 2.84 & 0.78 & & 3.19 & 0.95 & \\
\hline
\end{tabular}


In table 1 above, both principals and teachers agreed that involvement of teachers in school decision-making will give them broader opportunities to make inputs in matters that concern instructions, given their respective mean scores of 2.78 and 3.02 that are higher than the criterion mean score of 2.50. Furthermore, items 2, 3, 4 and 5 were also agreed by the respondents as being part of the various ways that involvement of teachers in decision-making enhances school effectiveness and students' achievement.

Research Question Two: In what ways does parents' participation in school management enhances students' academic performance in Rivers State?

Table 2: Mean scores and standard deviations (SD) of the ways parents' participation in school management enhances students' academic performance in Rivers State

\begin{tabular}{|c|c|c|c|c|c|c|c|}
\hline S/n & \multicolumn{2}{|c|}{ Description of Items } & \multicolumn{3}{|c|}{ Principal } & \multicolumn{3}{c|}{ Teachers } \\
\hline 6. & $\begin{array}{c}\text { Parents' participation in school decision- } \\
\text { making gives parents platform to offer their } \\
\text { advices on how to improve the quality of } \\
\text { teaching to enhance students' performance. }\end{array}$ & 2.67 & 0.71 & Agree & 3.33 & 0.68 & Agree \\
\hline 7. & $\begin{array}{c}\text { Involvement of parents in decision-making } \\
\text { helps to strengthens drives to generate } \\
\text { additional resources to fund school projects. }\end{array}$ & 2.98 & 0.81 & Agree & 3.37 & 0.88 & Agree \\
\hline 8. & $\begin{array}{c}\text { Parents' participation in decision-making } \\
\text { provides opportunities for parents to make a } \\
\text { case for centring management decisions on } \\
\text { improvement of students' achievement. }\end{array}$ & 3.01 & 0.69 & Agree & 3.41 & 0.83 & Agree \\
\hline $\begin{array}{c}\text { Involvement of parents in management gives } \\
\text { parents the sense of collective ownership of the } \\
\text { school that impels them to demand for } \\
\text { accountability in school financial transactions }\end{array}$ & 3.14 & 0.75 & Agree & 3.38 & 0.71 & Agree \\
\hline 10. & $\begin{array}{c}\text { Parents involvement in school decision-making } \\
\text { through PTA strengthens school's relationship } \\
\text { with its' host communities. }\end{array}$ & 3.03 & 0.88 & Agree & 3.07 & 0.92 & Agree \\
\hline & Grand Mean & $\mathbf{2 . 9 7}$ & $\mathbf{0 . 7 7}$ & & $\mathbf{3 . 3 1}$ & $\mathbf{0 . 8 0}$ & \\
\hline
\end{tabular}

In table 2 above, item 6 indicates that both principals and parents agreed that involvement of parents in school decision-making gives them good platform to offer their meaningful advises on how to enhance the quality of education as revealed by their respective mean scores of 2.67 and 3.33. Furthermore, items 7, 8, 9 and 10 were also agreed by the respondents as the various ways that active participation of parents in school decision-making can increase school effectiveness and enhance students' academic performance.

Hypothesis One: There is no significant difference between the mean perception of principals and teachers on the ways teachers' participation in school management enhances students' academic performance in Rivers State. 
Ebunu, A. A. (2020). Participatory Management for Enhancing Students' Academic Performance in Public Secondary Schools in Rivers State. Advances in Social Sciences Research Journal, 7(5) 145-156.

Table 3: Z-test of the difference between the mean perception of principals and teachers on the ways teachers' participation in school management enhances students' academic performance in Rivers State.

\begin{tabular}{|c|c|c|c|c|c|c|c|c|}
\hline S/No & Respondents & N & Mean & SD & DF & z-cal. & z-crit. & Remark \\
\hline 1. & Principals & 90 & 2.84 & 0.78 & \multirow{2}{*}{448} & 4.00 & 1.96 & $\begin{array}{c}\text { Significant } \\
\text { (Hojected) }\end{array}$ \\
\hline 2. & Teachers & 360 & 3.19 & 0.95 & & & & \\
\hline
\end{tabular}

Data in 3 suggest that z-cal (4.00) is higher than the table value (1.96) at the 448 degrees of freedom and 0.05 significance level, and thus indicated that significant difference existed between the mean perception of principals and teachers on the ways teachers' participation in school management enhances students' academic performance in Rivers State. Consequently, the null above hypothesis is rejected.

Hypothesis Two: There is no significant difference between the mean perception of principals and teachers on the ways parents' participation in school management enhances students' academic performance in Rivers State.

Table 4: Z-test of the difference between the mean perception of principals and parents on the ways parents' participation in school management can improve students' academic performance in Rivers State.

\begin{tabular}{|c|c|c|c|c|c|c|c|c|}
\hline S/No & Respondents & $\mathbf{N}$ & Mean & SD & DF & z-cal. & z-crit. & Remark \\
\cline { 1 - 7 } 1. & Principals & 90 & 2.97 & 0.77 & \multirow{2}{*}{368} & 4.20 & 1.96 & $\begin{array}{c}\text { Significant } \\
\text { (Ho rejected) }\end{array}$ \\
\cline { 1 - 6 } 2. & Parents & 280 & 3.31 & 0.80 & & & & \\
\hline
\end{tabular}

Data in 3 suggest that z-cal (4.20) is higher than the table value (1.96) at the 368 degrees of freedom and 0.05 significance level, and thus indicated that significant difference existed between the mean perception of principals and parents on the ways parents' participation in school management enhances students' academic performance in Rivers State. Consequently, the null above hypothesis is rejected.

\section{SUMMARY OF FINDINGS}

1. The study revealed that involvement of teachers in school decision-making enhances the opportunity for teachers to make inputs in policy issues that concern effective instructional delivery, empowers teacher to take decisions on issues concerning their respective subject matters and also builds relational trust which interplay with other factors to enhance teacherproductivity for enhanced students' achievement, etc.

2. The study showed that involvement of parents in school decision-making enhances parents' opportunities to offer their advices on how to improve the quality of teaching to enhance students' performance. The study also revealed participative management gives parents the sense of collective ownership of the school which impels them to demand for accountability in school financial transactions, etc. 
3. The study also showed that significant difference existed between the mean perceptions of principals and teachers on the ways teachers' participation in school management enhances students' academic performance in Rivers State.

4. The study also showed that significant difference existed between the mean perceptions of principals and teachers on the ways parents' participation in school management enhances students' academic performance in Rivers State.

\section{FINDINGS AND DISCUSSIONS}

The findings of this study had shown that involvement of teachers in school decision-making will give teachers broader opportunity to make inputs in policy issues that concern effective instructional delivery. The study also revealed that increasing the decision-making powers of teachers on their respective subject specialty will enhance instructional effectiveness and academic performance of students. These findings are in accord with the findings of Nadeem (2012:11), who reported that teacher participation in school management offered teachers increased decision making power that created enabling environment for administrators to perform their functions so effectively students' academic performances increased very markedly. The scholar reported that participative management was more effective in private schools than in public schools where school principals had difficulties in applying participatory management due to bureaucratic constraints.

The study further showed that involvement of teachers in school management will create a platform for robust discussion of management issues such as provision of physical facilities and welfare for teacher, which will in turn spur greater productivity, performance effectiveness and enhanced learning outcomes. This agrees with Lawal et al (2011) who observed that involvement of teachers in school governance offers them good opportunity to present to the school leadership, their instructional challenges for broad discussion in order to arrive at sustainable solution that will add to effective teaching and students' achievement. In addition, participative management gives teachers ample platform to air views on issues of concerns. When matters of concerns are raised by teachers and properly addressed by school's leadership, the issue of teacher dissatisfaction and attrition will rarely arise as teachers will not only feel valued by the school but also pride themselves as having played a part in the successes recorded in the school, including better performance on the part of students (Duze, 2011:202).

The study further revealed that teachers' participation in decision-making builds relational trust which interplay with other factors to foster teacher-productivity and students' performance. The study showed that the involvement of teachers in school decision-making strengthens power balance to give teachers control over their working lives. These findings are in line with Ebunu (2018) who observed that participative decision-making help to establish trust, functional relationship and royalty between teachers and the school leadership in management issues. Under such atmosphere is greater understanding in discussion of management issues in a productive and participative manner that will doubtlessly produce good decisions and good results that when applied will add value to students' productivity (Wong, 2003:76). Nadeem (2012:9) remarked that participative management promotes shared planning, organizing and coordination of respective school activities, with the result that teachers are given greater authority to influence school policy formulation and implementation procedures. Consequently, increasing the involvement and responsibility of teachers such as forming and appointing them as team and committee members for a given task will enable them to exercise their leadership skills as part of empowerment for 
Ebunu, A. A. (2020). Participatory Management for Enhancing Students' Academic Performance in Public Secondary Schools in Rivers State. Advances in Social Sciences Research Journal, 7(5) 145-156.

expanding their management skills beyond classroom levels. Although the traditional bureaucracy that characterize public schools' management system does not really give principals much reason not to apply authoritarian leadership style. Nadeem (2012:10) found out that $60 \%$ of public-school principals were likely to be autocratic in their leadership style. No wonder this study revealed that statistically significant difference existed between the mean ratings of the principals and teachers on the ways teachers' participation in school management improves students' academic performance. However, the concept of 'zone of acceptance' as postulated by Edwin Bridges in 1952 as explained by Abraham (2013:85) posits that principals should endeavour to involve teachers in decision-making concerning issues that are outside their zone of acceptance. The scholar argued that involving teachers that have high stake and expertise on matter of concern should be involved in a participative decision-making, whereas teachers that have no stake and expertise in matters of discuss should be excluded in such decision-making.

Furthermore, the study showed the ways in which parents' participation in school management can improve students' academic performance. The study showed that the involvement of parents in school decision-making will give them ample platform to offer their advices on how to improve the quality of teaching and learning and students' achievement. More so, the involvement of parents in decision-making was found to be pertinent for strengthening the drives towards resourcing for additional funds for effective financing school projects that have bearings to students' academic achievement. These findings are in consonant with Ukaigwe and Igbozuruike (2019:96) because the scholars observed that parents through PTA meeting offer reasonable suggestions that often have far-reaching implications on school policy issues that cut-across student academic progression, healthy living among students, and conducive school environment and sound moral and spiritual development of individuals in the school. However, Peretomode (1992:254) expressed concern that many schools' leadership often disregard the advises coming from parents via PTA meetings, arguing that such attitude is contrary to the objectives of PTA, which is to foster good relationship among staff, parents and students in a supportive manner that promote enabling environment for the advancement of school objectives and effective teaching and better learning outcomes. The scholar further called for the decentralization of school management bureaucracy via the enactment of enabling statutes that ought to empower parents to make useful contribution in school governance.

The study further revealed that parents' participation in decision-making provides opportunities for parents to make a case for centring management decisions on the improvement of students' achievement. This finding is in tandem with the Ukaigwe and Igbozuruike (2019:95) who observed that prior to take-over of schools in 1970s, parents used to play key role in decision-making process through the PTA meetings. Mulwa et al. (2015:61) suggested that PTA meetings communiqué usually highlights resolutions and recommendations to the school on areas of improvements, such as the importance of regular curriculum planning and modifications to align with economic and occupational skill needs of the host and surrounding communities.

This study further found out that involvement of parents in management decision-making gives parents the sense of collective ownership of the school that impels them to demand for accountability in school financial transactions in order to promote financial discipline and prudence, which will in long run lead to the attainment of educational objectives. In addition, the study showed that parents' involvement in school decision-making through PTA meetings and in 
expanded general meetings helps to strengthens school's relationship with schools' host communities. These findings agree with the findings of Shaeffer (1994), who stated that involvement of parents in school governance is more than fund raising because PTA meeting provide forum where parents, community leaders and teachers interact and share ideas on how to improve the quality of education students received, promote good moral and ethical standards among the teachers, plan and sponsor school events such as inter-house sport, Christmas or end of the year party, quiz competition and holiday lessons among other programmes aimed at enhancing students' academic performance and to give them nice time .

Furthermore, Obi (2003:278) asserted that parents use PTA meetings as avenue to air their opinion during discussions on ways of raising funds to procure instructional resources and facilities required for quality teaching and learning. The scholar further remarked that deliberation and resolutions arising from PTA meetings are usually but not limited to how to improve school curriculum in order to make it more responsive to learners needs, how to source for funds for the procurement of teaching facilities, how to respond to teachers' welfare demands to motivate and increase their performance, and how to collaborate with school council to accomplish strategic school projects that has direct bearing on the advancement of students' long and short terms academic goals. This study further found out principals and parents had similar but statistically different views on ways parents' involvement in school management can enhance students' achievement. The reason for the differences could be that some principals believed that bringing parents and even teachers into management issues may usurp their power and undermine the legitimacy of their authority. Although these misconceptions seem to be widespread among principals, yet the fact remains that parents only use the platform created by PTA meetings to air their views and make suggestions on how to better manage the school to improve students' academic performance.

\section{CONCLUSION}

Based on the findings, this study concludes that active involvement of teachers and parents in school management offers great benefits to school management practices. This is because involvement of teachers in school decision-making will give teachers broader opportunities to make inputs in matters that concern instruction in a manner that enhances instructional effectiveness and students' achievement.

\section{RECOMMENDATIONS}

Based on the findings, the following recommendations were made;

1. School managers should give teachers meaningful opportunities to make inputs in policy issues that concern effective instructional delivery given that such opportunities will empower them to take decisions on issues affecting their work performance and productivity for enhanced students' achievement.

2. School authorities should accord parents' opportunities to offer their advices on how to enhance resource accountability to foster efficient school management and quality teaching and learning in the school.

\section{References}

Abraham, N. M. (2013). Educational Administration in Nigeria. Port Harcourt: Pam Unique Publishing Coy. Ltd. 
Ebunu, A. A. (2020). Participatory Management for Enhancing Students' Academic Performance in Public Secondary Schools in Rivers State. Advances in Social Sciences Research Journal, 7(5) 145-156.

Duze, C. O. (2011). Students and teachers participation in decision-making and impact on school work and school internal discipline in Nigeria. African Research Review, 5(2), 200-214.

Ebunu, A. A. (2018). Principal's managerial skills for effective administration of public Secondary Schools in Delta state. (Unpublished master dissertation). University of Port-Harcourt, Port Harcourt, Nigeria.

Educational Development Centre (2004). Community school alliance project. The global learning group, Ghana. Retrieved on 13th June 2012 at http://www2.ede.org/CSAC

Freeman, R. (2010). Strategic management: A stakeholder approach, Cambridge: Cambridge University Press.

Lawal, B. Z. \& Yusuf, M. O (2014). The impact of participatory decision making in organizational management. International Journal of Marketing and Technology, 4(3), 3-4.

Mullins, J.L. (2008). Management and Organizational Behaviour. (7th ed.). United Kingdom: Pearson Education LTD.

Mulwa, D. M., Kimosop, M. K. \& Kasivu, G. M. (2015). Participatory governance in secondary schools: The students viewpoint in eastern region of Kenya. Journal of Education and Practice, 6(30), 59-65.

Nadeem, M. (2012). Participative management style: A tool to enhance quality education. Journal of Humanities and Social Science, 4(2), 08-14

Nwankwo, I.N. (2014). Students' participation in decision making and its implications for educational leadership. Journal of Emerging Trends in Educational Research and Policy Studies 5(3), 362-367.

Obi, E. (2003). Educational management and practice. Enugu: Nigeria; Jamoe Enterprises

Peretomode, V. F. (1992). Education law: Principles, cases and materials on Schools: Owerri, International Universities Press Ltd, 217-257.

Shaeffer, S. (1994). Partnerships and participation in basic education: a series of training modules and case study abstracts for educational planners and mangers. Paris: UNESCO, International Institute for Educational Planning.

Ukaigwe, P. C., \& Igbozuruike, I. U. (2019). Planning: A tool for administration of teachers' competence development programmes for improved service delivery in secondary schools in Rivers State, Nigeria. Advances in Social Sciences Research Journal, 6(1), 91-100.

Uwakwe, C. U., Falaye, A. O., Emunemu, B.O. and Adelore, O. (2008). Impact of decentralization and privatization on the quality of education in Sub-Saharan Africa: The Nigerian Experience. European Journal of social sciences, 7(1), 5467 